\title{
3. STRUCTURAL MAP OF THE GALICIA MARGIN ${ }^{1}$
}

\author{
Michel Thommeret and Gilbert Boillot, Laboratoire de Géodynamique Sous-Marine du CEROV, \\ Villefranche-sur-Mer, France \\ and \\ Jean-Claude Sibuet, IFREMER, Centre de Brest, Brest, France
}

\begin{abstract}
All available seismic data have been used to establish a new structural map of the Galicia passive margin. The northsouth syn-rift normal faults that bound the tilted fault blocks are interrupted and/or slightly offset by a discrete pattern of transverse faults oriented $\mathrm{N} 55^{\circ}-\mathrm{N} 70^{\circ}$ and $\mathrm{N} 115^{\circ}-\mathrm{N} 135^{\circ}$.
\end{abstract}

\section{INTRODUCTION}

The western Galicia margin (Fig. 1) is one of the world's best examples of a starved passive continental margin. It is characterized by a series of parallel tilted blocks, formed during the rifting stage of the margin (Berriasian-late Aptian; see "Site 638" chapter; Boillot, Winterer, et al., 1987) and overlain by a thin post-rift sedimentary cover (latest Aptian-Present). The purpose of this short paper is to consider the entire seismic data set collected separately by the Institut Français du Pétrole, IFREMER, and Paris University (Montadert et al., 1979; Sibuet, Ryan, et al., 1979; Groupe Galice, 1979; Boillot et al., 1979, 1986; Sibuet et al., 1987; Mauffret and Montadert, 1987) and to establish an up-to-date structural map of the area drilled in 1985 during Leg 103 of the Ocean Drilling Program (ODP).

\section{STRUCTURE OF THE GALICIA MARGIN}

A total of about $5000 \mathrm{~km}$ of seismic profiles was used to establish the new structural map presented in this paper. Figure 2 shows the locations of these track lines. The $1250 \mathrm{~km}$ of multichannel seismic data allows us to interpret unambiguously the $3750 \mathrm{~km}$ of single-channel seismic profiles. In developing this structural map (Fig. 3), we chose to delineate only those features that appear on all of the seismic profiles. These features include:

1. The normal faults mapped at the top of the syn-rift sequence (i.e., at the level of the break-up unconformity).

2. The axes of the half-graben basins, also identified at the level of the top of the syn-rift sequence. These axes could locally differ from the half-grabens axes, but we chose this definition because the lowermost sedimentary section of the basins cannot be identified on all of the single-channel seismic profiles.

3. The summit of tilted blocks or ridges.

4. The horizontal projection of fault escarpment, from the top to the break-up unconformity.

Several observations can be made from the structural map, including:

1. The tilted fault blocks are continuous over distances up to $60 \mathrm{~km}$ and are oriented $\mathrm{N}^{\circ} \pm 20^{\circ}$. Spacing between blocks has a mean value of $16.3 \mathrm{~km}$ and varies from 7.2 to $35.7 \mathrm{~km}$ (mea-

\footnotetext{
${ }^{1}$ Boillot, G., Winterer, E. L., et al., 1988. Proc. ODP, Sci. Results, 103: College Station, TX (Ocean Drilling Program).
}

surements made along east-west profiles at intervals of $10 \mathrm{nmi}$ from $41^{\circ} 50^{\prime} \mathrm{N}$ to $42^{\circ} 40^{\prime} \mathrm{N}$ ).

2. The north-south tensional features are interrupted and/or slightly offset over short distances $(\sim 20 \mathrm{~km})$ by transverse faults oriented $\mathrm{N} 55^{\circ}-\mathrm{N} 70^{\circ}$ or $\mathrm{N} 115^{\circ}-\mathrm{N} 135^{\circ}$ (Fig. 4). Some of the vertical offsets along the transverse faults are equivalent to those along the north-south normal faults. As most of the seismic profiles are oriented east-west, perpendicular to the margin trend (Fig. 2), the north-south features are well defined. On the contrary, the transverse features that slightly offset the tilted block trend can only be partly constrained. Note that transverse faults are not continuous across the entire margin (Le Pichon and Sibuet, 1981). Normal and transverse faults were active during the Early Cretaceous rifting stage, and the transverse faults seem to have accommodated latitudinal variations of extension.

3 . The peridotite ridge to the west of the Galicia margin (Fig. 3) is composed of serpentinized harzburgite or lherzolite ("Site 637" chapter; Boillot, Winterer, et al., 1987; Boillot et al., 1980, 1986, 1987; Sibuet et al., 1987). The ridge runs parallel to the tilted blocks and seems to be unaffected by the transverse faults. At least locally, its morphology is similar to that of the tilted fault blocks (Mauffret and Montadert, 1987). Syn-rift deposits overlie its eastern flank, suggesting that the ridge was emplaced at the end of the rifting stage of the margin, probably at the rift axis.

\section{CONCLUSIONS}

The new structural map established from the available seismic data recorded on the western Galicia margin gives a precise picture of the principal features that were active during the rifting stage of the margin. It provides a basic structural framework for interpretation of ODP Leg 103 data presented in this Proceedings.

\section{ACKNOWLEDGMENTS}

We thank L. Montadert for the communication of seismic lines recorded by the Institut Français du Pétrole.

Contribution no. 434 of the Groupe d'Etude de la Marge Continentale, Université Pierre et Marie Curie, Paris, and CNRS UA 718. Contribution of IFREMER, Centre de Brest.

\section{REFERENCES}

Boillot, G., 1986. Comparison between the Galicia and Aquitaine margins. Tectonophysics, 129:243-255.

Boillot, G., Auxiètre, J.-L., Dunand, J.-P., Dupeuble, P.-A., and Mauffret, A., 1979. The northwestern Iberian margin: a Cretaceous passive margin deformed during Eocene. In Talwani, M., Hay, W., 
Ryan, W.B.F. (Eds.), Deep Drilling Results in the Atlantic Ocean: Continental Margins and Paleoenvironment: Am. Geophys. Union, Maurice Ewing Ser., 3:138-153.

Boillot, G., Comas, M. C., Girardeau, J., Kornprobst, J., Loreau, J.-P., Malod, J., Mougenot, D., and Moullade, M. 1986. Fonds sousmarins basaltiques et ultramafiques au pied d'une marge stable. Résultats préliminaires de la campagne Galinaute (plongées du submersible Nautile à l'ouest de l'Espagne). C. R. Acad. Sci. Ser. 2, 303:1719-1724.

Boillot, G., Grimaud, S., Mauffret, A., Mougenot, D., Mergoil-Daniel, J., Kornprobst, J., and Torrent, G., 1980. Ocean-continent boundary off the Iberian margin: a serpentinite diapir west of the Galicia bank. Earth Planet. Sci. Lett., 48:23-24.

Boillot, G., Recq, M., Winterer, E., Meyer, A. W., Applegate, J., Baltuck, M., Bergen, J. A., Comas, M. C., Davies, T. A., Dunham, K., Evans, C. A., Girardeau, J., Goldberg, D. G., Haggerty, J., Jansa, L. F., Johnson, J. A., Kasahara, J., Loreau, J.-P., Luna-Sierra, E., Moullade, M., Ogg, J., Sarti, M., Thurow, J., and Williamson, M. A., 1987. Tectonic denudation of the upper mantle along passive margins: a model based on drilling results (ODP Leg 103, western Galicia margin, Spain). Tectonophysics, 132:335-342.

Boillot, G., Winterer, E. L., 1987. Proc. ODP, Init. Repts., 103: College Station, TX (Ocean Drilling Program).

Groupe Galice, 1979. The continental margin off Galicia and Portugal: acoustical stratigraphy, dredge stratigraphy and structural evolution. In Sibuet, J.-C., Ryan, W.B.F., et al., Init. Repts. DSDP, 47, Pt. 2: Washington (U.S. Govt. Printing Office), 633-662.
Lallemand, F., Mazé, J.-P., Monti, F., and Sibuet, J.-C., 1985. Présentation d'une carte bathymétrique de l'Atlantique nord-est. $C$. $R$. Acad. Sci. Ser. 2, 300:145-149.

Laughton, A. S., Roberts, D. G., and Graves, R., 1975. Bathymetry of the northeast Atlantic. Sheet 3: Mid-Atlantic Ridge to southwest Europe. Deep Sea Res., Part A, 22:792-810.

Le Pichon, X., and Sibuet, J.-C., 1981. Passive margins: a model of formation. J. Geophys. Res., 86(B5):3708-3720.

Mauffret, A., and Montadert, L., 1987. Rift tectonics on the passive continental margin off Galicia (Spain). Mar. Petrol. Geol., 4:49-69.

Montadert, L., de Charpal, O., and Sibuet, J.-C., 1979. Northeast Atlantic passive margin: rifting and subsidence processes. In Talwani, M., Hay, W., Ryan, W.B.F. (Eds.), Deep Drilling Results in the Atlantic Ocean: Continental Margins and Paleoenvironments: Am. Geophys. Union, Maurice Ewing Ser., 3:154-186.

Sibuet, J.-C., Mazé, J.-P., Amortilla, P., and Le Pichon, X., 1987. Physiography and structure of the western Iberian continental margin off Galicia from Sea Beam and seismic data. In Boillot, G., Winterer, E. L., et al., Proc. ODP, Init. Repts, 103: College Station, TX (Ocean Drilling Program), 77-98.

Sibuet, J.-C., Ryan, W.B.F., et al., 1979. Init. Repts. DSDP, 47, Pt. 2: Washington (U.S. Govt. Printing Office).

Date of initial receipt: 3 August 1987

Date of acceptance: 8 February 1988

Ms 103B-185 


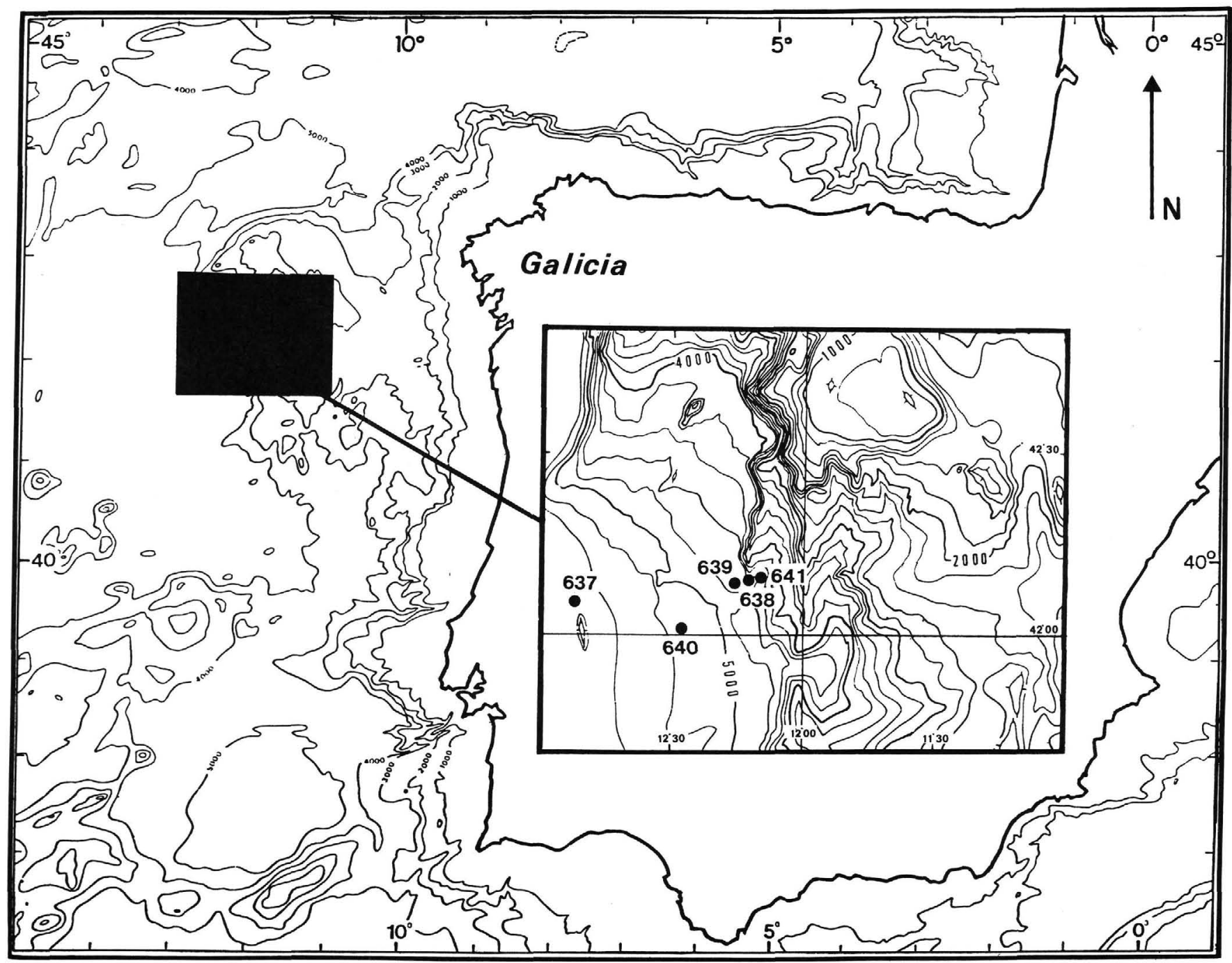

Figure 1. Location of the studied area. Black box is the location of Figures 2 and 3. Bathymetry in meters, after Laughton et al. (1975). The positions of the ODP Leg 103 drill sites are plotted on the Sea Beam data for the area, after Lallemand et al. (1985). 


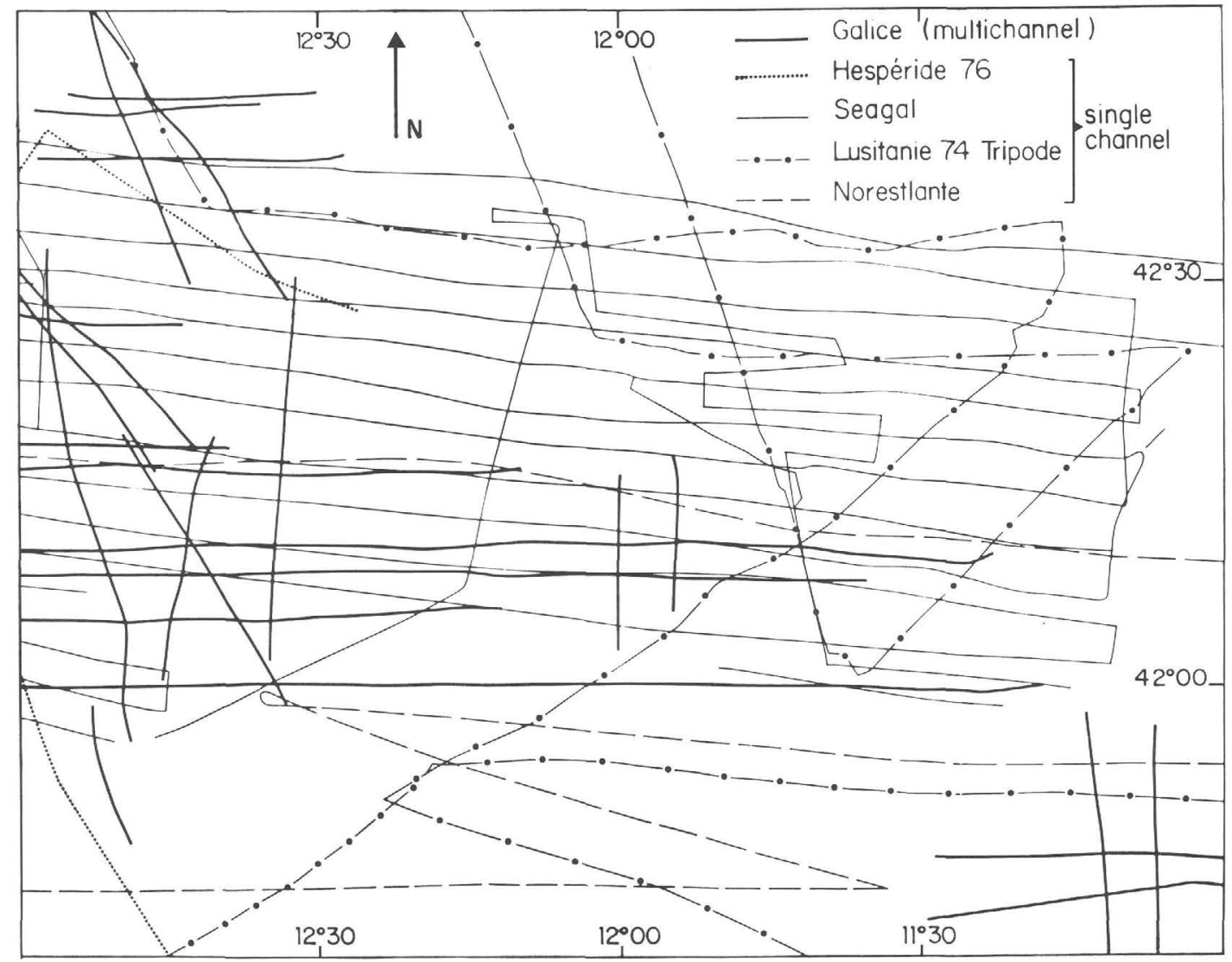

Figure 2. Location of the seismic lines used in this study. Galice profiles were recorded by the Institut Français du Pétrole; Norestlante and Seagal profiles were recorded by IFREMER, Centre de Brest; and Hesperides, Lusitanie, and Tripode profiles were recorded by University of Paris. 


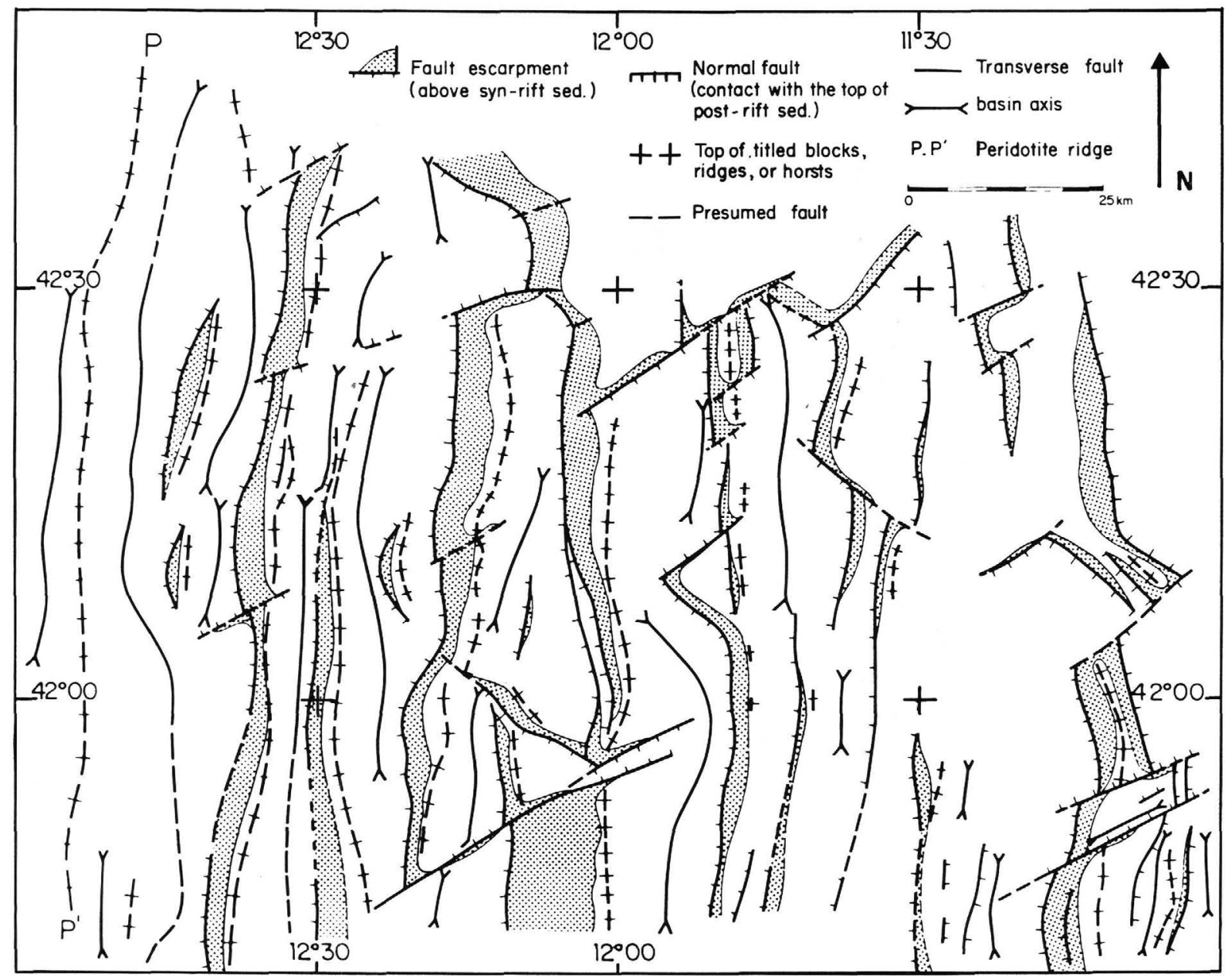

Figure 3. Structural map of the deep Galicia margin (location on Fig. 1). This map was established from interpretation of the seismic lines shown in Figure 2. 


$$
i
$$

